\title{
Jaka przyszłość globalnej gospodarki?
}

\begin{abstract}
Artykuł podejmuje kwestie związane z obecnym etapem globalizacji. Analizuje główne przyczyny ekonomicznej i społecznej kontrrewolucji antyliberalnej oraz podkreśla jej wpływ na nowo rodzący się kształt światowego tadu gospodarczego. Finansyzacja gospodarki światowej, będąca w dużej mierze rezultatem niekontrolowanych dostatecznie rynków finansowych, jak i bardzo dotkliwe dla społeczeństw bańki spekulacyjne, przyczynity się m.in. do zakwestionowania modelu rozwojowego opartego głównie na rynkach, bez należytego wsparcia regulacyjnego i kontrolnego ze strony państwa. Skoro istnieje coraz powszechniejsze przekonanie, że na obecnym etapie rozwoju gospodarczego globalizacja oparta na neoliberalnych zasadach powinna być gruntownie przemyślana, to w jakim kierunku powinny nastąpić korekty lub zmiany obecnego stanu. Autor podziela punkt widzenia Josepha E Stiglitza, że Unia Europejska jest taką organizacja, która może i powinna w większym stopniu stanowić punkt odniesienia dla integracji gospodarczej i społecznej, a przez to i dla nowo kształtującego się globalnego ładu ekonomicznego. Zwiększenie integracji politycznej, regulacyjnej i stymulacyjnej roli państwa w gospodarce nie oznacza zastępowania rynkowej konkurencyjności, poprzez politykę protekcjonizmu i nacjonalizmu ekonomicznego.
\end{abstract}

Słowa kluczowe: globalizacja, kontrrewolucja antyliberalna, paradygmat rozwojowy, Unia Europejska, Nowa Ekonomia Strukturalna.

\section{Wprowadzenie}

Interwencja na szeroką skalę ostatecznych pożyczkodawców (rządów i banków centralnych) zakończyła eskalację utraty płynności finansowej przez zdecydowaną większość podstawowych światowych podmiotów gospodarczych i finansowych (banki komercyjne, fundusze inwestycyjne, fundusze ubezpieczeniowe etc.). Spowodowało to wzrost optymizmu w gospodarce globalnej. Według najnowszych prognoz Organizacji Współpracy Gospodarczej i Rozwoju (OECD), gospodarka światowa wzrośnie w roku 2018, a także w 2019 r. o 3,9 procent, czyli najwięcej od 2011 roku. Przyspieszenie tempa nastąpi głównie za sprawą ożywienia w handlu i w inwestycjach ${ }^{1}$. Charakterystyczna wydaje się jednak opi-

1 https://www.ppr.pl/wiadomosci/oecd-gospodarka-swiatowa-w-2018-i-2019-r 
nia jednej z najbardziej prestiżowych brytyjskich gazet ekonomicznych, która prognozuje, że „globalizacja przetrwała wiele rzeczy, ale inwazja merkantylistycznego populizmu może być dla niej wyzwaniem największym od dziesięcioleci. Rok 2018 nie jest bynajmniej dla międzynarodowego handlu katastrofalny, ale może się okazać rokiem trwożnego wyczekiwania na wybuch wojen handlowych" (Financial Times, 2018).

Istnieje poważna obawa, że coraz więcej rządów, dostrzegając słabości obecnego etapu globalizacji, może przesadnie chronić przed zagraniczną konkurencją swoje gospodarki, w nadziei, że przyniesie to dobre rezultaty ekonomiczne i społeczne.

Coraz częściej stawiane jest również pytanie o rolę państwa i rynku w procesach gospodarczych. Poprzedni światowy kryzys finansowy postawił w centrum uwagi m.in. kwestię kontroli międzynarodowych przepływów kapitału. Teraz, w szczególności, w odniesieniu do gospodarek wschodzących pojawia się kwestia zasadności wprowadzenia określonych narzędzi kontroli transferu kapitału (Wojtyna, 2017), lecz temat ten zasługuje na oddzielne potraktowanie.

\section{Przyczyny ekonomiczne i społeczne kontrrewolucji antyliberalnej}

Jeden z najpoważniejszych ośrodków analitycznych na świecie - The Economist Intelligence - uważa, że potencjalny problem tkwi także w tym, że obecne i przyszłe działania prezydenta Donalda Trumpa wpisują się w obecny trend w światowej gospodarce. A mianowicie, coraz więcej krajów otwarcie mówi o tym, by zamykać swoje gospodarki przed zagraniczną konkurencją lub przynajmniej bardziej koncentrować się na wykorzystaniu własnych zasobów.

Jednakże problem jest znacznie poważniejszy i głębszy. W książce pt. Nowy Pragmatyzm kontra Nowy Nacjonalizm Grzegorz W. Kołodko trafnie zauważa, że występujące obecnie na świecie zjawiska i procesy społeczno-gospodarcze są coraz bardziej skomplikowane i konfliktogenne (Kołodko i Koźmiński, 2017). Gotów on jest przypisać je w dużej mierze nierównowadze zarówno społecznej, jak i gospodarczej, ale również procesom demograficznym oraz zagrożeniom naturalnego środowiska człowieka. Jego zdaniem, zjawiska te nie są jeszcze dostatecznie objaśnione przez nauki ekonomiczne, ponieważ - jak twierdzi - dotychczasowe szkoły ekonomii, a zwłaszcza ekonomii głównego nurtu, okazują się przestarzałe, nieadekwatne dla nowych problemów i w tym zakresie należy poszukać czegoś nowego (Kołodko i Koźmiński, 2017, s. 11). 
Andrzej K. Koźmiński uważa z kolei, że „ludzie na całym świecie zaczynaja aspirować do coraz wyższego poziomu dobrobytu, i jak dawniej, w minionych wiekach, pokornie godzili się ze swoim losem, tak w chwili obecnej takiej zgody już nie ma i występuje potencjał gwałtowanego protestu" (Kołodko i Koźmiński, 2017, s. 11).

Pogląd ten koresponduje $\mathrm{z}$ głównymi konkluzjami badań Thomasa Piketty'ego, który w swojej książce pt. Kapitat w XXI wieku stwierdza, iż „dynamika akumulacji kapitału prywatnego prowadzi nieuchronnie do coraz większej koncentracji bogactw i władzy w kilku rękach...” (Piketty, 2015, s. 11). Piketty konkluduje: „Kiedy wskaźnik rentowności kapitału przewyższa w sposób trwały stopę wzrostu produkcji i dochodu, jak działo się to do XIX wieku i może stać się normą w wieku XXI, kapitalizm automatycznie tworzy arbitralne nierówności nie do zniesienia, stawiając pod znakiem zapytania podstawowe wartości, na jakich opierają się nasze demokratyczne społeczeństwa" (Piketty, 2015, s. 11). Wątpi on, iżby „równoważące się siły wzrostu, konkurencji i postępu technicznego prowadziły spontanicznie do redukcji nierówności i harmonijnej stabilizacji w zaawansowanych fazach rozwoju, jak myślał Kuznets w XX wieku" (Piketty, 2015, s. 11). W swoich badaniach Piketty słusznie zagłębia się w historię, chce bowiem wykazać tezę, że amerykańskie marzenie, czyli obietnica egalitarnego kapitalizmu w stylu zachodnim, nie jest w stanie się spełnić i prawdopodobnie w przyszłości nic się tu nie zmieni. W systemie tym bowiem tempo wzrostu gospodarczego jest zawsze niższe od stopy zysku z zainwestowanego kapitału. Ze wzrostu korzysta całe społeczeństwo, z zysku natomiast - jedynie najbogatsi (Piketty, 2015, s. 373).

Profesor Studiów Europejskich na Uniwersytecie w Oksfordzie, Jan Zielonka, w książce pt. Kontrrewolucja. Liberalna Europa $w$ odwrocie, próbuje dostrzec przyczyny, które stały i stoją u podstaw „kontrrewolucji” antyliberalnej i ustanowienia rządów i partii politycznych kwestionujących liberalną odmianę demokracji oraz reformy rynkowe oparte na konsensusie waszyngtońskim (Zielonka, 2018). „W całej Europie politykę w coraz większym stopniu postrzegano jako sztukę instytucjonalnej inżynierii, nie zaś jako sztukę negocjacji między elitami a elektoratem. Coraz więcej władzy powierzano instytucjom nie wyłanianym w wyborach powszechnych - bankom centralnym, sądom konstytucyjnym, agencjom regulacyjnym - by upewnić się, że podejmowaniem decyzji politycznych będzie rządzić rozum, nie zaś namiętności. Uleganie naciskom społecznym uważano za nieodpowiedzialne, jeśli nie wręcz niebezpieczne... Mówiono, że obywateli należy raczej edukować niż słuchać” (Zielonka, 2018, s. 24). 
Choć to zaskakująca diagnoza Profesora o poglądach liberalnych, który, mimo wspominanej wyżej krytyki, wierzy jednak w odrodzenie nowego liberalizmu, zasługuje na przytoczenie. Mamy bowiem do czynienia, przynajmniej na kontynencie europejskim i w Stanach Zjednoczonych, z wyraźnie zauważalnymi tendencjami, które przekładają się jednocześnie na charakter i architekturę nowego ładu ekonomicznego i społecznego.

Dani Rodrick już wcześniej twierdził, że istnieje konflikt między demokracją, nieograniczoną globalizacją gospodarczą i autonomią bądź suwerennością państw. Dowodził, że niemożliwa jest koegzystencja tych trzech celów polityki na poziomie państwa narodowego.

Brytyjski tygodnik „The Economist” (2018) w analizie pn. Dlaczego demokracja umiera przypomniał, że w 1941 roku na świecie było tylko kilka demokracji. Za to do 2000 roku tylko w 8 krajach nie przeprowadzono wolnych wyborów. W badaniach dokonanych w 38 krajach, 4 na 5 osób preferowało wtedy system demokratyczny. Wtedy to właśnie, w 1989 roku, Francis Fukuyama wieszczył „koniec historii” - demokracja zwycięży - system liberalnej demokracji będzie powszechny, a gospodarka rynkowa niezagrożona (Fukuyama, 2009).

Dziś, jak pisze tygodnik „The Economist”, mamy do czynienia z odwrotem od demokracji. Pismo próbuje przytoczyć potwierdzające to przykłady i je zracjonalizować. Proces tego odwrotu wyraźnie przyspieszył w czasie kryzysu finansowego w latach 2007-2009, a wraz z postępującą destabilizacją spowodowaną migracją i nasileniem konfliktów zbrojnych:

1) narosły odczucia społeczne, że elity demokratyczne nie potrafią sobie poradzić w pełni lub całkowicie z pokonaniem kryzysu oraz napięciami na tle politycznym i społecznym. Największy kryzys finansowy od czasu depresji lat trzydziestych, narastający kryzys zadłużenia w Europie, biliony publicznych pieniędzy przekazane na ratowanie banków, pogłębiające się nierówności majątkowe, to wszystko przeraziło i sfrustrowało miliony osób;

2) nie pojawiło się wielu nowych silnych przywódców o demokratycznych przekonaniach w rodzaju Konrada Adenauera, Margaret Thatcher czy ojców założycieli Unii Europejskiej. Pojawili się za to silni przywódcy (strongmeni), którzy podważyli zaufanie do demokracji liberalnej i dotychczasowych elit.

Nowi silni przywódcy (strongmeni) zaproponowali natomiast:

- rozmontowanie lub ograniczenie dotychczasowych instytucji i obyczajów demokratycznych;

- wykreowanie i poszukiwanie wroga (Donald Trump za głównego wroga uznał elity demokratyczne i liberalne). W zamian nastąpiło poszukiwanie nowych elit, ale takich, które są lojalne, posiadają kwalifikacje, które nie kwestionują 
autorytetu przywódcy (także od strony intelektualnej). Elity islamskie z kolei przestraszyły się rosnącej roli nowych elit świeckich - nieudany, co prawda, zamach w Turcji był jednak dla nich sygnałem zagrożenia ich pozycji;

- nową politykę gospodarczą, która odwołuje się do pojęcia suwerenności gospodarczej i inaczej definiowanego interesu narodowego w warunkach procesów globalizacji.

\section{Znaki zapytania w sprawie międzynarodowego ładu}

Wszystkie powyższe rozważania prowadzą także do postawienia znaków zapytania związanych z dotychczasowym ładem w skali światowej, a szczególnie z ładem gospodarczym. Do niedawna paradygmat rozwojowy oparty był na wspomnianym konsensusie waszyngtońskim. Wyrastał on nie tylko z naukowych badań, lecz także realnych tendencji, występujących w procesie globalizacji. Megatrendy w gospodarce światowej to przede wszystkim: deregulacja, liberalizacja, prywatyzacja i integracja. Te cztery główne tendencje, występujące w gospodarce światowej, stały się zasadniczym kanonem polityki ekonomicznej wielu państw.

Podstawowe wytyczne konsensusu dla polityki gospodarczej ulegały z czasem pewnym modyfikacjom, jednak ich główny trzon nie podlegał zmianom. $\mathrm{W}$ globalnej gospodarce stały się swego rodzaju wzorcem rozwojowym dla bardzo wielu państw o różnym stopniu zaawansowania ekonomicznego i społecznego. Momentem przełomowym weryfikującym ustalenia konsensusu stał się niespodziewany, co do skali i rozmiarów, światowy kryzys finansowy w latach 2007-2009. Pewne założenia teoretyczne teorii ekonomicznych opartych na wierze w samoczynne mechanizmy naprawcze wolnego rynku nie sprawdziły się. Co więcej, system, pozbawiony mechanizmów regulacji zaczął „produkować” różnego rodzaju wynaturzenia. Szczególnie dotkliwe dla gospodarki, ale i zwykłych obywateli okazały się „błędy i wypaczenia”, które pojawiły się na rynkach finansowych (Nowak, 2013). Narastały także problemy natury społecznej i politycznej, o których wcześniej napisano w tej rozprawie. Konsensus waszyngtoński, wyrosły z neoliberalnych teorii, został poważnie zakwestionowany.

Niemniej jednak jednoznacznie negatywne oceny skutków jego implementacji są także nieuprawnione. Można znaleźć też przykłady państw, które, realizując wspomniane założenia, doświadczyły internacjonalizacji swojej produkcji i dystrybucji, transferu i importu nowoczesnych technologii, rewolucji informatycznej, rozwoju nowych rynków etc. Polityka gospodarcza, oparta na konsensusie stała się istotnym elementem transformacji systemowej w wielu krajach tzw. gospodarek wschodzących, w tym i Polski. 
Jednak bezkrytyczna wiara w samoczynne mechanizmy naprawcze „wolnego rynku" nie sprawdziła się, co, jak wspomniano, ukazał w szczególności światowy kryzys finansowy (2007-2009), którego skutki - jak się wydaje - nie zostały ostatecznie i trwale przezwyciężone. Finansyzacja gospodarki światowej, będąca w dużej mierze rezultatem niekontrolowanych dostatecznie rynków finansowych, czy bardzo dotkliwe dla społeczeństw bańki spekulacyjne przyczyniły się m.in. do zakwestionowania modelu rozwojowego opartego głównie na rynkach, bez należytego wsparcia regulacyjnego i kontrolnego ze strony państwa. Do krytyki modelu, którego podstawą są zasady neoliberalne dołączyć można wszystkie inne ich konsekwencje: frustracje i nierówności społeczne, polityczne, ekologiczne zagrożenia, o których napisano wcześniej.

\section{Charakterystyka nowych tendencji globalizacyjnych}

Rozważania należy poprzedzić ogólną charakterystyką nowych tendencji w gospodarkach najważniejszych krajów świata oraz konsekwencji nowych zjawisk w procesie globalizacji.

- Coraz szybciej postępuje rewolucja technologiczna. Zbieranie i przechowywanie ogromnych ilości informacji do celów analitycznych w różnych dziedzinach praktykowane było od dawna. Dziś jednak gwałtowny wzrost i dostępność danych (big data), a jednocześnie ich zaprogramowana selekcja prowadzą do uzyskania jakościowo nowych możliwości. Łączenie i zestawianie relacji, hierarchii i różnorodnych powiązań, zbieranie i selekcjonowanie danych z różnych źródeł, w szczególności w sferze gospodarczej, otwiera nowe możliwości podejmowania szybkich i bardziej wiarygodnych decyzji oraz zmian w strategiach biznesowych. $\mathrm{Z}$ tej postępującej technologicznej rewolucji korzystają w pierwszej kolejności wielkie korporacje transnarodowe. One najszybciej dysponują zasobami umożliwiającymi dopasowywanie, oczyszczanie i przekształcanie danych w różnych systemach, również po to, aby uzyskać przewagę konkurencyjną na globalnym rynku.

- W wielu krajach (np. Chiny, Indie, Izrael) obserwujemy szybkie przechodzenie od rozwoju imitacyjnego do rozwoju opartego na innowacjach. Prowadzi to do coraz większych sporów, a nawet konfliktów, np. w kwestii przestrzegania praw autorskich.

- Kryzys finansowy lat 2007-2009 zmienił na trwałe dynamikę rozwojową tradycyjnych i nowo rodzących się potęg gospodarczych. Kontynent azjatycki staje się jednym z najważniejszych centrów gospodarki światowej. A co także 
bardzo ważne - pojawianie się nowych potęg gospodarczych wcale nie opiera się wyłącznie na zasadach neoliberalnych. Nawet Międzynarodowy Fundusz Walutowy zakwestionował główne założenia konsensusu waszyngtońskiego.

- Coraz bardziej bezwzględna rywalizacja na globalnym rynku odbywa się w sytuacji, gdy pokłady naturalnych zasobów na ziemi są na wyczerpaniu. Ale pojawiają się również opinie, że jeszcze groźniejszy na dłuższą metę jest brak wspólnej troski o ochronę środowiska naturalnego i spory wokół polityki klimatycznej.

- Pogłębia się podział na beneficjentów i outsiderów współczesnej globalizacji. Jak wspomniano wcześniej, rosną nierówności, stawiając pod znakiem zapytania podstawowe wartości, na jakich opierają się współczesne społeczeństwa. Wywołuje to bunt i narastanie sprzeciwu wobec praktyk globalizmu i jego bezkrytycznych obrońców.

- Wszystkie wymienione wcześniej zjawiska w różnym stopniu sprzyjają pojawieniu się nacjonalizmów gospodarczych i przekonaniu, iż w obliczu słabości i ułomności dotychczasowych tendencji występujących na globalnych rynkach należy wprowadzić jakieś formy protekcjonizmu, ograniczeń w wolnym handlu, nawet jeśli potencjalnie grozić to będzie wybuchem konfliktów handlowych. Takie podejście wzmacnia też rolę, wydawało się już nieco mniej eksponowanego znaczenia, soft i hard power poszczególnych państw.

Ów „nowy nacjonalizm”, jak nazywają go autorzy książki (Kołodko i Koźmiński, 2017, s. 7) - „Nowy pragmatyzm, czy nowy nacjonalizm” charakteryzuje się w obecnych warunkach również „odrodzeniem agresywnych postaw, poglądów i polityki, która wydawało się, wygasła już raz na zawsze po straszliwych doświadczeniach dwóch wojen światowych". Tak więc w globalnej rywalizacji o charakterze gospodarczym wraca znaczenie polityki zagranicznej, która zakłada połączenie soft i hard power (m.in. czynników politycznych i manipulacyjnych) jako istotnych elementów skutecznie chroniących i wzmacniających interes narodowy.

\section{Globalizacja, ale jaka?}

Skoro istnieje coraz powszechniejsze przekonanie, że na obecnym etapie rozwoju gospodarczego globalizacja oparta na neoliberalnych zasadach powinna być gruntowanie przemyślana, to w jakim kierunku powinny nastąpić korekty lub zmiany obecnego stanu? Czy istnieje realistyczna koncepcja, aby skorzystać z nieodwracalności procesu globalizacji z jego także pozytywnymi rezultatami, 
ale dla coraz większej ilości państw świata. A jednocześnie, jak trzeba zminimalizować ewidentne słabości i wynaturzenia, skutkujące narastającą groźną degradacją społeczną i buntem wielu społeczeństw?

Ktoś, kto tylko w jednej dziedzinie skutecznie zaprojektuje i zapanuje nad żywiołem i siłą współczesnych rynków, w tym przede wszystkim rynków finansowych, a przez to zmieni w istotny sposób procesy i wektory globalizacji, zasłuży na Nagrodę Nobla.

Warto jednak przynajmniej nie popełniać nowych błędów lub nie warto wspierać tych scenariuszy zmian, które mogą potencjalnie tworzyć nowe zagrożenia, a może i nowe, poważne konflikty. Próby rozwiązywania sprzeczności naturalnych interesów koncernów czy państw poprzez formy indywidualnego protekcjonizmu, politykę nakładania ceł, zastępowanie rynkowej konkurencyjności, prowadzenie agresywnych strategii politycznych, zastępujących mechanizmy ponadnarodowych negocjacji i uzgodnień, doprowadzą najpewniej jedynie do powrotu egoizmów narodowych.

Tymczasem w globalnej gospodarce, gdzie istnieje także obiektywna rywalizacja i walka o interesy narodowe, państwa narodowe skazane są raczej na porażki, ponieważ poprzez realne niebezpieczeństwo izolacjonizmu lub separacji państwa te mają znacznie mniejsze możliwości realizacji swoich interesów. Dotyczy to nawet tak potężnych i wiodących krajów, jak Stany Zjednoczone. Choć do niedawna wydawało się to niemożliwe.

Zwiększenie regulacyjnej i stymulacyjnej roli państwa w gospodarce - jako konieczny postulat ograniczenia niekorzystnych procesów zachodzących na globalnym rynku - nie oznacza wyboru na rzecz ograniczania integracji i światowego handlu czy próby zastępowania rynkowej konkurencyjności poprzez politykę protekcjonizmu i nacjonalizmu ekonomicznego. Przy wszystkich mankamentach, integracja i swobodny przepływ technologii, kapitału i siły roboczej to jedne z najsilniejszych impulsów rozwojowych w skali państw, regionów i świata. „Zbiurokratyzowane wszechmogące państwo jest tak samo nie do przyjęcia, jak całkowity wolny rynek" (Nowak i Ryć, 2017, s. 81).

\section{Gdzie szukać dodatkowych impulsów rozwojowych?}

Skoro próba zastąpienia dotychczasowego ładu na drodze różnych form hegemonii jego głównych aktorów, a nie poprzez próby konsensusu, zostałaby zrealizowana, to globalna gospodarka będzie stawała się jeszcze poważniejszym zarzewiem globalnych konfliktów. Procesy globalizacji należy zatem poddać 
większej kontroli ze strony organizacji ponadnarodowych lub za pośrednictwem regulacji prawnych i innych, które zostaną uzgodnione poprzez konsensus lub przynajmniej poprzez większość państw. Będzie to wszakże niesłychanie trudne do zrealizowania. Realistycznie oceniając, nadzieja, iż jest możliwy na szczeblu globalnym „nowy pragmatyzm” ze strony głównych aktorów światowej gospodarki, wydaje się być płonna. Warto więc poszukać rozwiązań sprawdzonych w ujęciu nie tyle globalnym, ile regionalnym.

\subsection{Spójrzmy na Unię Europejską}

Unia Europejska jest taką organizacją, która może i powinna w większym stopniu stanowić punkt odniesienia dla integracji gospodarczej i społecznej, a przez to szerzej - dla globalnego ładu.

Laureat Nagrody Nobla, Joseph E. Stiglitz, w książce pt. Euro. W jaki sposób wspólna waluta zagraża przyszłości Europy (2017), który przekonująco ukazuje, jak dotychczasowe rozwiązania, szczególnie w strefie euro, przyczyniają się raczej do tworzenia rozbieżności niż spójności w europejskiej wspólnocie, zadaje pytanie, czy Europa może rozwijać się bez euro? W odróżnieniu od większości ekonomistów amerykańskich, Stiglitz pozytywnie rozważa, jak stworzyć strefę euro, która będzie działać. Podkreśla on swoją nadzieję, że to co proponuje przyczyni się do wdrożenia rozwiązań, które zapewnią kontynentowi dobrobyt i „wesprą naszą solidarność”. Jednak zakłada również, że jeśli przeprowadzenie gruntowanych reform, które proponuje, okaże się niemożliwe do wykonania, „Europa musi zdecydować się na porzucenie euro, aby ocalić projekt o wiele ważniejszy - projekt politycznej integracji, istotny nie tylko dla Starego Kontynentu, lecz także dla całego świata" (Stiglizt, 2017, s. 69).

Joseph Stiglitz jest przekonany, że jeśli wspólna waluta ma działać, to „potrzeba nam więcej Europy”. Precyzuje przy tym, że nie chodzi mu od razu o federację na kształt Stanów Zjednoczonych, gdzie dwie trzecie wszystkich wydatków publicznych ma miejsce na poziomie centralnym, ale o zdecydowane podniesienie obecnego stopnia integracji. Bardziej sprawny Jednolity Rynek i swobodna migracja wymagają „więcej Europy”. Tym bardziej więc wspólna waluta wymaga „więcej Europy” (Stiglizt, 2017, s. 69). Zaproponowane przez niego plany reform i gruntowanych zmian, które w konsekwencji mają prowadzić do uratowania strefy euro i projektu europejskiego zasługują na oddzielne potraktowanie, ponieważ kraje strefy euro bez dalszych reform, ale i bez akceptacji dla nich nadal będą narażone na pogłębienie dywergencji i konflikty.

J. Stiglitz spogląda jednak na Unię Europejską i strefę euro szerzej - w kontekście globalizacji. Pisze on, że „wciąż toczy się debata; jakie są warunki uda- 
nej globalizacji. Co robić, jeśli wcale nie przebiega ona tak, jak byśmy sobie tego życzyli? Jakie niesie za sobą koszta i kto na niej zyskuje? Kto przegrywa? W tym sensie sukcesy i porażki Europy są dobrą lekcją na przyszłość - zarówno, jak chodzi o integrację regionalną, jak i tę naukę na poziomie światowym...”. Stiglitz na przykładzie Unii Europejskiej podkreśla, że „integracja gospodarcza (globalizacja) nie powiedzie się, jeśli pozostawi w tyle integrację polityczną. Rośnie więc potrzeba działań kolektywnych - tak by mieć pewność, że wzajemne korzyści będą większe od wyrządzanych sobie nawzajem szkód" (Stiglizt, 2017, s. 69). Przy wszystkich zastrzeżeniach odnośnie do obecnego etapu funkcjonowania Unii Europejskiej i strefy euro, Joseph E. Stiglitz, traktuje Unię Europejską jako istotny projekt, ważny nie tylko dla Starego Kontynentu. Jak podkreśla „powodzenie projektu europejskiego leży nie tylko w interesie Europy”.

Europejską regionalizację można postrzegać jako istotny element globalizacji. Jednak wychodzenie Wielkiej Brytanii z UE oraz nie do końca przezwyciężone skutki kryzysu finansowego lat 2007-2009 czy mankamenty strefy euro stawiają jednak pewne znaki zapytania nad podążaniem za europejskim modelem rozwojowym. Tym bardziej, że pojawiły się nowe azjatyckie potęgi gospodarcze, które uczyniły kontynent azjatycki jednym z najważniejszych centrów gospodarki światowej i tym samym zmieniają wektory globalizacji.

\section{Globalizacja z polskiej perspektywy}

Korzyści płynące z integracji gospodarki polskiej z gospodarką światową w ramach Światowej Organizacji Handlu (WTO) oraz Unii Europejskiej i uczestnictwo w procesie globalizacji pociągnęły za sobą także pewne zjawiska ujemne, które należy traktować jako koszty. Jednak w ogólnym bilansie korzyści przeważają nad kosztami.

Jako kraj doganiający państwa najbardziej rozwinięte, Polska dokonuje także rewizji powszechnie uznawanych teorii ekonomicznych. W większym stopniu przygląda się i wyciąga praktyczne wnioski z doświadczeń tych krajów, które osiągnęły sukces gospodarczy, nie podążając klasyczną drogą neoliberalizmu. Natomiast zwraca zdecydowanie większą uwagę na rozwój gospodarczy jako proces przemian strukturalnych i politykę przemysłową, która jest ważnym narzędziem pozwalającym wytyczać priorytety $\mathrm{w}$ zakresie wykorzystania ograniczonych zasobów. Stąd też zainteresowanie polskich władz doktryną Nowej Polityki Strukturalnej, której jednym z najważniejszych autorów jest chiński ekonomista Justin Yifu Lin. Istota tej doktryny polega na tym, iż czynnikiem 
o znaczeniu decydującym dla sukcesu rozwojowego jest państwo, które umożliwia ten rozwój, prowadząc odpowiednią politykę przemysłową. Jak wskazuje Justin Y. Lin, rozwój gospodarczy jest procesem przemian strukturalnych. Pożądana polityka przemysłowa powinna mieć zatem na celu ułatwianie rozwoju branż posiadających ukryte przewagi konkurencyjne, ale również powinna pomóc firmom w wychodzeniu z tych branż, w których dany kraj traci przewagi komparatywne. Na konkurencyjnym rynku rządy winny wynagradzać przedsiębiorstwa za wnoszenie wartości dodanych do domeny publicznej, wypracowanych przez pierwszych inicjatorów w nowych branżach - tych, w których kraj posiada ukryte przewagi komparatywne - ale także zapewniać i koordynować wspieranie twardej i miękkiej infrastruktury, aby obniżać koszty transakcyjne (Lin, 2017, s. 199-200).

Polska w pewnych segmentach polityki gospodarczej korzysta obecnie ze wskazań Nowej Ekonomii Strukturalnej, szczególnie poprzez bardziej aktywną rolę państwa, usuwanie barier inwestycyjnych w celu nadrobienia opóźnienia technologicznego w wielu ważnych sektorach gospodarki. Polska w warunkach globalnej gospodarki chce więc uwolnić i uruchomić istniejący potencjał wzrostu, a przez to osiągnąć sukces rozwojowy. Szuka więc w praktyce rozwiązań, które pozwolą jej jak najkorzystniej zaistnieć w zmieniających się realiach gospodarki światowej.

\section{Bibliografia}

De Grauwe, P. i Ji, Y. (2018). Inżynieria finansowa nie ustabilizuje niestabilnej strefy euro. Obserwator Finansowy, 19 kwietnia.

Financial Times. (2018). Komentarz redakcyjny, 28.06.2018.

Fukuyama, F. (2009). Koniec historii. Kraków: Wydawnictwo Znak.

http://globaleconomy.pl

https://www.ppr.pl/wiadomosci/oecd-gospodarka-swiatowa-w-2018-i-2019-r

Kołodko, G.W. i Koźmiński, A.K. (2017). Nowy Pragmatyzm Kontra Nowy Nacjonalizm. Warszawa: Wydawnictwo Prószyński i S-ka.

Krugman, P. (2008). The Return of Depression Economics and the Crisis of 2008. December. USA: W.W. Norton\&Company Inc.

Lin, J.Y. (2017). Nowa Ekonomia Strukturalna dla gospodarek doganiających. W: J.Y. Lin, A.Z. Nowak (red), Nowa Ekonomia Strukturalna wobec krajów mniej zaawansowanych. Warszawskiego: Wydawnictwo Naukowe Wydziału Zarządzania Uniwersytetu Warszawskiego.

Nowak, A.Z. (2013). Współczesny świat w erze turbulencji. W: J. Bogdanienko, W. Piotrowski (red.), Zarzadzanie: tradycja i nowoczesność. Warszawa: PWE.

Nowak, A.Z., Wojtaszczyk, K.A. i Zamęcki, Ł. (2016). Poland in the European Union. Coleccion Universidad 8. Madrid: Schedas. 
Nowak, A.Z. i Ryć, K. (2017). Polityka w regionach w warunkach globalizacji. Warszawa: Wydawnictwo Naukowe Wydziału Zarządzania Uniwersytetu Warszawskiego.

Nowak, A.Z. i Lin, J.Y. (2017). New Structural Economics for Less Advanced Countries. Warszawa: Wydawnictwo Naukowe Wydziału Zarządzania Uniwersytetu Warszawskiego. Nowak, A.Z. i Taplin, R. (2010). Intelectual Property, Innovation and Management in Emerging Economics. London: Routledge.

Piketty, Th. (2015). Kapitat w XXI wieku. Warszawa: Wydawnictwo Krytyki Politycznej.

Stiglitz, J.E. (2006). Making Globalization Work. USA: W.W. Norton\&Company Inc., September.

Stiglitz, J.E. (2008) The Triumphant Return of John Maynard Keynes. Guatemala Times, 5 December.

Stiglizt, J.E. (2017). Euro. W jaki sposób wspólna waluta zagraża przysztości Europy. Warszawa: Wydawnictwo Krytyka Polityczna.

The Economist. (2018). Why the democracy dies, 16 June, No. 12.

Wojtyna, A. (2017). Nowa faza dyskusji o kontroli międzynarodowych przepływów kapitału. Gospodarka Narodowa, listopad - grudzień.

Wojtyna, A. (2008). Współczesna ekonomia - kontynuacja, czy poszukiwanie paradygmatu. Ekonomista, 1 .

Zielonka, J. (2018). Kontrrewolucja. Liberalna Europa w odwrocie. Warszawa: PWN. 